\title{
SABLE AT SHINGWEDZI
}

\section{By Ronin Tomininson}

In May and June I spent three weeks in the Kruger National Park, staying at Skukuza, Letaba, Shingwedzi and Satara. Though all these places are intensely interesting, in many ways Shingwedzi is the best of all. Being the northernmost camp, except Punda Maria, it is less frequented, and the country -more genuinely wild than the southern districts which are easier to reach and very crowded in the tourist season.

Shingwedzi became part of the reserve in 1903, when there was very little left there to preserve. It is, therefore, most satisfying to see such a wonderful variety there now, and to find that many animals, notably waterbuck and impala, have become so tame. In the four days we spent there, we saw vast numbers of impala, very many greater kudu and waterbuck, a herd of fifteen sable antelope, a few roan antelope, tsessebe, zebra, wild dog, steinbok, bushbuck and quantities of birds. The elephant were also there in strength, and everywhere were palms, mopani and other trees which they had pulled down. Indeed in some places the bush looked as though a bull-dozer had been through it. We saw no lion or giraffe, though in the south we had seen many of both.

The camp itself is very pleasant, and is inhabited by flocks of glossy starlings, which are gentian blue, shot with green and purple, and have golden eyes. They are very tame, and even sit on the trbles outside the huts and eat from your hand. The Impala lily, a bushy plant with lovely crimson and white starshaped flowers, has been planted there; when a glossy starling alights on it, the colour is unforgettable.

The country around Shingwedzi is very beautiful, especially near the rivers, which are fringed with Ilala palms, grey-green with fan-shaped leaves, wild date palms with feathery lenves of a brighter green, and many large dark green shade trees. In June the rivers are dried up, lenving occasional water-holes. Away from the watercourses the bush is mainly mopani, which, in May, was turning colour, and looked almost like an English bech-wood in autumn, very lovely in the low, cvening sunlight.

One of the ronds follows the river for some distanec, and on the rondside are open glades among the trees; here impnla and other antelope can be seen more easily than in places where the grass is long and the bush dense. One morning we started at 6.0 a.m. just before sunrise, and drove along this river road. In the carly light everything looked benutiful and mysterious, 
and the first herd of impala were very close-one old ram, about thirty ewes and perhaps twenty young ones. These were playing like fairies, floating, almost flying around, as they chased each other in circles, and moving in a delightfully effortless way as only impala can. Even these young antelope seemed a pinkish colour in the sunrise, and the dry feathery grasses were pink too in the patches of sunlight among the trees. With the opal-coloured sky in the background and the grey-green leaves of Ilala palms, the whole scene was like a beautiful ballet, performed by most enchanting dancers. A little farther on we saw a baby waterbuck with a herd of impala. We feared his mother had been killed by a lion, and he was prancing around rather awkwardly, trying to behave like an impala! We hoped one of them would adopt him, but I do not know if that ever happens.

Near the river were herds of waterbuck, usually one buck with about ten does, lying close to the edge of the road, chewing the cud as peacefully as cows in a meadow, and quite unafraid of our car. $A$ small herd of roan were much less tame; they looked at us for a moment with their curiously marked faces and huge ears, and then drifted away into the bush. The kudu cows, on the contrary, were very tame, and we saw many lovely groups of three or four, with perhaps a young one or two, and an old bull. These great kudu bulls were very clusive and would glide about behind the trees with their wonderful spiral horns camouflaged among the twisted branches. But if one of them did come into the open, how magnificent he looked, with his noble head and horns and greyish fawn cont striped with white. If it was carly morning and the sun behind him, the light brown mane on the crest of his neck appeared golden, and the linings of his large and beautiful cars, palc pink.

The Shingwedzi elephants were rather a drawback from the point of vicw of watching other things, as they were apt to turn up suddenly and very silently, and be rather too close before one realized it. After secing the kudu, we came upon two clephants quite close on our right. While watching them, I heard a parrot scream on the left, turned to look, and there was a third clephant advancing towards us, not aggressively, but as though he wanted to cross the rond, and might object to a car in his way. So we thought it was time to move on!

Not far bcyond the clephants a bushbuck doe was standing about twenty yards from the edge of the road. She gazed at us for several minutes while we admired her lovely cyes and large delicate enrs. It was interesting to see what a large number of waterbuck, and also impala rams, had, in fighting, lost all or 
part of one horn. These unfortunates were, of course, outcasts and alone, or with a few younger males.

But the highlight of our stay at Shingwedzi was the moment when we saw the sable. We had looked eagerly for signs of them ever since entering the Park, and had heard of some near the Lower Sabi road, but had not seen them. Then at Shingwedzi we were told that a herd sometimes came to water quite near the camp. A few hundred yards beyond the camp gates a causeway crosses the river and there is a clear vicw for some distance up and down stream. Here, at the appointed time, we waited, but for the first two days saw no sable, though there were many other fascinating things to watch.

On the third day we waited for three-quarters or an hour. The sun was very fierce, and the air above the river bed was dancing in the heat. To our left, three elephants were having a happy time near some reeds on the edge of a water-hole. Ten or twelve waterbuck, having quenched their thirst, were lying out on the sand in the blazing sun, apparently quite comfortable. Two bush buck, a male and a female, stepped delicately from the steep bank on to the sand, and went across to the water. To our right, on the edge of a nearby pool, a flock of glossy starlings were bathing, and were soon joined by some doves and two lovely little brown-headed parrots, whose main colour is a brilliant green. Then a herd of about fifty impala, of all ages, walked in single file towards the pool, the old ram coming last. Next a fine kudu bull crossed majestically to a water-hole a little farther upstream, three tsessebe were moving among the trees on the river bank, and some baboons and ground hornbills had come to the nearest pool when the impala left.

All this was sufficiently thrilling, but then, for no particular reason, I turned to the left, and there-in full view some two hundred yards away, was a perfect fricze of fiftecn sable antelope, walking proudly in single file townrds the water. $\Lambda$ youngish bull, quite black, but with only moderate horns, came first; next, several young bulls, less black, and some young cows, which were brown; five cows of a rich dark brown, ench with a small light brown calf, and then a little behind the rest, the king of the herd. IHe was a magnificent old gentleman, jet black except for the snowy white of his face, stern and underparts. When they neared the water, he halted and stood sentincl, looking superbly arrogant, the sweep of his horns an inspiration.

We had waited a long while for the Snble, but when they deigned to show themselves, they did so in the most perfect way imaginable. 